was demystified and its endorphin-enhancing health benefits promoted. Addiction psychology reframed lovesickness as "co-dependence." And, in the 1980s, sexually charged illness gained international prominence with HIV and the various manifestations of hepatitis $\mathrm{C}$, a disease that has been shaped by our ambivalence about the "goodness of love."

Although the liver has played a central role in medicine since antiquity, technological advances in the 19th and early 20th centuries allowed a detailed understanding of what had previously been considered jaundice. A link between blood transfusions, infectious hepatitis and HIV eventually led to highly publicized events such as the Krever inquiry. In the process, those infected with hepatitis $\mathrm{C}$, identified through a blood test but otherwise experiencing no apparent illness, were medicalized, tainted with the "bad" type of infection usually reserved for drug addicts and homosexuals. Yet only half of asymptomatic cases of hepatitis $C$ progress to a serious physiological illness. Asymptomatic hepatitis $C$ represents an illness "caused by an invading organism and also by factors external to the patient: by the scientific discoveries; by the $\mathrm{Kr}$ ever inquiry; by journalists, politicians, lawyers, and jurists; and by the compensation packages."

How readers regard this book will depend on their background and expectations. Philosophically, the topics mirror the Cartesian body-soul divide. For some, this may be a stretch. Is Agape (v. Eros) in ancient Greece the same as "courtly love" in the time of chivalry? Is it meaningful to juxtapose 17th-century paintings of lovesickness against 20thcentury sexually transmitted diseases? At what point do sweeping generalizations usher in what Tolstoy called the "slyness of reason"? For doctors, as for their patients, human suffering is a common thread that transcends shifting medical terms and a labyrinth of philosophical theory. Sexually charged illnesses stand at a particularly vulnerable intersection between culture and biology, often colouring our relationships with patients who are sick but whose symptoms resist an easy reduction to physical causes. And Duffin's latest book can serve to stimulate discussion about the "lurid metaphors with which they have been landscaped."

\section{Dorian Deshauer}

Department of Psychiatry

University of Ottawa

Ottawa, Ont.

\section{References}

1. Sontag S. Illness as metaphor and AIDS and its metaphors. New York: Farrar, Straus and Giroux; 1990. p. 4.

2. Tepper ML, Gully PR. Lovers and livers: hepatitis B as an STD. Can F Hum Sex 1997:6:2.

\section{IIIness and metaphor}

\section{Elizabethan talk therapy}

Rosalind, disguised as a man, offers to cure the lovesick Orlando, who does not realize he is speaking to the object of his affection.

ROSALIND: No: I will not cast away my physic but on those that are sick. There is a man haunts the forest, that abuses our young plants with carving 'Rosalind' on their barks; hangs odes upon hawthorns, and elegies on brambles; all, forsooth, deifying the name of Rosalind: if I could meet that fancymonger, I would give him some good counsel, for he seems to have the quotidian* of love upon him.

ORLANDO: I am he that is so love-shaked. I pray you, tell me your remedy.

ROSALIND: Love is merely a madness, and, I tell you, deserves as well a dark house and a whip as madmen do; and the reason why they are not so punished and cured is, that the lunacy is so ordinary that the whippers are in love too. Yet I profess curing it by counsel.

\section{ORLANDO: Did you ever cure any so?}

ROSALIND: Yes, one, and in this manner. He was to imagine me his love, his mistress; and I set him every day to woo me: at which time would I, being but a moonish youth, grieve, be effeminate, changeable, longing and liking; proud, fantastical, apish, shallow, inconstant, full of tears, full of smiles, for every passion something, and for no passion truly anything, as boys and women are for the most part cattle of this colour: would now like him, now loathe him; then entertain him, then forswear him; now weep for him, then spit at him; that I drave my suitor from his mad humour of love to a living humour of madness, which was, to forswear the full stream of the world, and to live in a nook merely monastic. And thus I cured him; and this way will I take upon me to wash your liver as clean as a sound sheep's heart, that there shall not be one spot of love in't.

From William Shakespeare, As You Like it, Act III, Scene ii. *quotidian: a fever recurring daily 